\title{
Historical lead seals and the influence of disinfectants on the lead corrosion rate
}

\author{
Sarka Msallamova*iD, Milan Kouril, Kristyna Charllote Strachotova, Jan Stoulil, Kateryna Popova \\ and Pavla Dvorakova
}

\begin{abstract}
Lead used to be a common material for setting seal to historical documents. Lead seals formed parts of historical documents as a guarantee of their legal validity. Disinfectants are commonly used during the restoration of historical documents. They successfully remove mould, bacteria and microscopic fungi from the surface of parchment documents. However, some disinfectants could also be a source of corrosion damage to lead seals. This work was carried out to examine possible corrosion damage to lead seals caused by disinfectants [a solution of carbethopendecinium bromide, a solution of glutaraldehyde, butanol (vapours), a solution of 1-propanol, 2-propanol + ethanol called Bacillol AF], which are commonly used during restoration of historical documents. The lead corrosion rates were determined by using lead resistometric probes. The solutions of carbethopendecinium bromide and glutaraldehyde increase the lead corrosion rate and corrosion products based on carbonates, nitrates and organic lead salts are formed on the lead surface. The most appropriate disinfectants for the restoration of historical documents with lead seals are alcoholbased solutions, such as butanol (vapours) and a solution of 1-propanol, 2-propanol and ethanol called Bacillol AF.
\end{abstract}

Keywords: Lead, Corrosion, Resistometric probe, Disinfectants, Seals, Historical documents

\section{Introduction}

The attaching of seals to documents has been common since ancient times in the area around the Mediterranean Sea [1]. The seal identified the owner and the confirmator of the document, protected the contents of the document and served as proof that the document was authentic. Seals were made as an impression of the matrix to the sealing medium. Seal matrices were made from iron, steel or, rarely, from ivory. The oldest way of sealing documents was by making an impression of the seal directly on the face of the historical document. From the 12th century seals were usually attached to documents with a silk thread, hemp cord, metal thread or parchment strip. Wax, lead or even gold seals were affixed to documents. Wax seals were affixed to common documents in the northern parts of Europe [2, 3]. Because of the climatic conditions in the south of the Alps, lead was more frequently used for seals. However, lead seals were used primarily by orders of knights and popes and Byzantine

*Correspondence: msallams@vscht.cz

University of Chemistry and Technology, Prague, Czech Republic emperors $[4,5]$. The oldest known papal lead seal dates back to the first half of the 6th century (Pope Agapetus in 535-536). Gold was used only for seals on royal and imperial documents of great importance [6, 7].

Lead is an amphoteric metal. Under atmospheric conditions, it is in a passive state and its surface is covered with a thin layer of $\mathrm{PbO}$ with a thickness of 3-6 nm [8]. The mechanism of the lead corrosion process under atmospheric conditions is described by the following equations [9]:

$$
\begin{aligned}
& \text { Anodic oxidation: } \mathrm{Pb}^{0} \rightarrow \mathrm{Pb}^{2+}+2 \mathrm{e}^{-} \\
& \text {Cathodic reduction: } 1 / 2 \mathrm{O}_{2}+\mathrm{H}_{2} \mathrm{O}+2 \mathrm{e}^{-} \rightarrow 2 \mathrm{OH}^{-} \\
& \text {Overall reaction: } \mathrm{Pb}^{0}+1 / 2 \mathrm{O}_{2}+\mathrm{H}_{2} \mathrm{O} \rightarrow \mathrm{Pb}^{2+}+2 \mathrm{OH}^{-}
\end{aligned}
$$

The composition of the corrosion products on a lead surface under atmospheric conditions is caused by the presence of air-borne pollutants. Carbon dioxide is a natural part of the atmosphere and, together with atmospheric moisture, causes the formation on the lead 
surface of $\mathrm{PbCO}_{3}, \mathrm{~Pb}_{3}\left(\mathrm{CO}_{3}\right)_{2}(\mathrm{OH})_{2}$ (hydrocerussite) and $\mathrm{Pb}_{10}\left(\mathrm{CO}_{3}\right)_{6} \mathrm{O}(\mathrm{OH})_{6}$ (plumbonacrite). The presence of sulphur dioxide in the atmosphere means that the layer of corrosion products on the surface of the lead can also contain $\mathrm{PbSO}_{4}$ (anglesite). At increased concentrations of nitrogen oxides in the atmosphere, the corrosion products can also contain $\mathrm{Pb}\left(\mathrm{NO}_{3}\right)_{2}$. In contrast to the above-described compounds, lead (II) nitrate is soluble and difficult to detect. In a maritime atmosphere, the lead corrosion products can also contain $\mathrm{PbCl}_{2}$ and $\mathrm{PbCl}(\mathrm{OH})$ (laurionite) $[8,9]$. In the enclosed indoor atmosphere of depositaries or museums, sulphane (hydrogen sulphide) and volatile organic compounds can also be present [8]. Because of the limited air circulation, their concentrations can be much higher than in the surrounding atmosphere. The corrosion products of lead can also contain lead (II) sulphide. All the above compounds (except lead (II) nitrate) are stable components of lead corrosion products. All of the above mentioned corrosion products are difficult to dissolve in water. Under atmospheric conditions, they do not participate in the further active corrosion damage to the lead matrix. On the lead surface, however, it produces an unsightly greyish-white layer. However, the corrosion on the surface of the lead forms unattractive layers that can distort the historical information of preserved objects [10].

In addition, volatile organic substances in the indoor atmosphere cause active corrosion of lead. This is especially true of acetic acid, acetaldehyde, formic acid and formaldehyde. The resulting corrosion products are well soluble in water. They participate in active corrosion of the lead matrix under atmospheric conditions. The mechanism of corrosive attack on lead in a damp atmosphere containing acetic acid is described by the following equation [11]:

$$
\mathrm{Pb}^{2+}+2 \mathrm{CH}_{3} \mathrm{COOH}+1 / 2 \mathrm{O}_{2} \rightarrow \mathrm{Pb}\left(\mathrm{CH}_{3} \mathrm{COO}\right)_{2}+\mathrm{H}_{2} \mathrm{O}
$$

$$
\begin{aligned}
& 3 \mathrm{~Pb}\left(\mathrm{CH}_{3} \mathrm{COO}\right)_{2}+2 \mathrm{CO}_{2}+4 \mathrm{H}_{2} \mathrm{O} \\
& \quad \rightarrow \mathrm{Pb}_{3}\left(\mathrm{CO}_{3}\right)_{2}(\mathrm{OH})_{2}+6 \mathrm{CH}_{3} \mathrm{COOH}
\end{aligned}
$$

Acetic acid acts as a catalyst in the reaction [12,13].

Volatile organic compounds in interior spaces can be derived from wood, oil-based or emulsion paints, some adhesives, plastics and disinfectant agents, etc. $[9,10]$.

It is difficult to restore historical documents with seals because the seals are inseparably attached to documents with textile ropes or parchment tapes. A historical document affixed with a seal is most frequently made of parchment. Following long-term storage, the surface of the parchment can be contaminated by various kinds of bacteria and microscopic fungi. Through their activity, they can irremediably damage the parchment support and text written on the parchment sheets. Thus, one of the steps in the restoration of historical documents involved their disinfection. In the middle of the 19th century, alcohol-based solutions began to be used for disinfection of historical documents. During the 20th century, substances based on quaternary ammonium salts (QAS) and aldehydes also began to be used for disinfection of historical documents [14]. The disinfectant effect of alcohols increases with increasing length of the carbon chain. An alcohol solution has a destructive effect on the cell membrane and causes coagulation and denaturation of proteins $[15,16]$. Quaternary ammonium salts (QAS) belong among cation-active tensides. QAS disturb the functioning of enzymes and can also coagulate proteins. QAS have somewhat limited effectiveness. They act effectively against negatively charged bacteria and microscopic fungi [17]. Aldehyde-based disinfectant agents are highly effective and act destructively against both bacteria and microscopic fungi, viruses and spores. Aldehydes effectively disrupt the functioning of enzymes and have reductive and alkylation properties [14]. Other possible ways of disinfecting parchment documents are using a laser [18], silver nanoparticles [19], gellan gum rigid hydrogels and titanium dioxide nanoparticles hydrogels [20, 21]. Historical parchment documents are disinfected using the following agents, among others (Table 1).

Disinfectants are applied to historical documents most often with swabs, coatings and brushes, local spraying or bandaging. Careless handling of disinfectants might contaminate the attached seals or cause the disinfectant to seep through the textile cords to the lead seals. It was the purpose of this study to assess the effect of selected disinfectant agents on the corrosion rate of lead using resistometric probes, the polarisation resistance values and the compositions of the corrosion products formed on the surface of the lead following exposure. The model laboratory experiment layout, suitable both for the electrochemical measurement of the corrosion rate of lead and for determining the corrosion rate of lead with resistometric probes, was used for testing.

\section{Experimental}

\section{Determining polarisation resistance values ( $R p)$}

The polarization resistance value is inversely proportional to the corrosion rate [22].

$$
\mathrm{Rp} \approx 1 / \mathrm{v}_{\mathrm{corr}}
$$

A Gamry PCI4 instrument was used for the measurement and the obtained data were evaluated using Gamry Framework software. The measurement was carried out using a pressure cell. The working electrode consisted of 
Table 1 Selected disinfectant

Name
Carbethopendecinium
bromide

a lead sample with a known area that was polished with P800 sandpaper and immersed in a solution of the tested disinfectant agent. A saturated calomel electrode (SCE) was used as the reference electrode and the counter electrode was a platinum wire.

\section{Parameters of the measurement}

- time of equilibration of EOC, $1800 \mathrm{~s}$

- polarization range $-15 \mathrm{mV} / \mathrm{EOC}$ to $+15 \mathrm{mV} / \mathrm{EOC}$

- scan rate $0.1 \mathrm{mV} \mathrm{s}^{-1}$.

The measurement was performed using a solution of disinfectant agent in distilled water (2\% carbethopendecinium bromide, $2.5 \%$ glutaraldehyde, solution of 1-propanol, 2-propanol and ethanol in an approximate ratio of 10:6:1 (Bacillol AF), 96\% butanol) and an artificial rain water solution $\left(0.85 \mathrm{~g} \mathrm{l}^{-1} \mathrm{Na}_{2} \mathrm{SO}_{4}\right)$ was used as the comparison solution. The measurement was repeated four times for each medium and all the measurements took place at room temperature in the presence of air.

\section{Determination of the lead corrosion rate $\left(\mathbf{v}_{\text {corr }}\right)$ using resistometric probes}

The method of determination of corrosion rates using resistometric probes is based on a change in the electrical resistance of a thin metal layer with time. The probe consists of the measuring and reference parts. The surface of the reference metal layer is covered with $3 \mathrm{M}^{\mathrm{TM}}$ Solar Ultra Barrier Film adhesive tape (Fig. 1).

If the metal layer on the measuring part of the probe corrodes, its thickness changes and its electric resistance increases. In this case, the metal layer was lead with an initial thickness of $25 \mu \mathrm{m}$. The AirCorr system was used to evaluate the data [23]. The measuring part of the resistometric probes was exposed before the measurement:

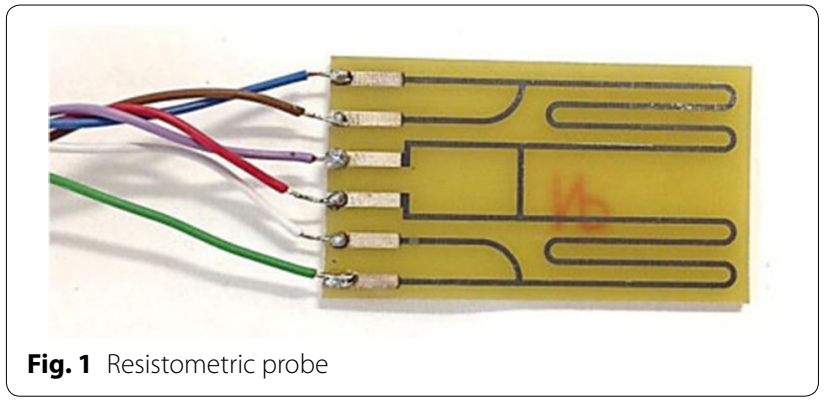

- by immersion of measuring part-2 min without rinsing, drying by a hot air stream (used for solutions of $2 \%$ carbethopendecinium bromide, $2.5 \%$ glutaraldehyde and a mixture of 1-propanol, 2-propanol and ethanol in an approximate ratio of 10:6:1 (Bacillol AF); the comparison solution was an artificial rain water solution $\left(0.85 \mathrm{~g} \mathrm{l}^{-1} \mathrm{Na}_{2} \mathrm{SO}_{4}\right)$

- over vapours-exposure for $48 \mathrm{~h}$ in a closed cell (used for 96\% butanol).

Then resistometric probes were suspended in the cell, in which $\mathrm{RH}=100 \%$ was maintained; the corrosion rate of lead with time was measured for $300 \mathrm{~h}$ using the AirCorr system. The measurement conditions correspond to the accelerated corrosion test. All the measurements took place at room temperature in the presence of air. The corrosion rate of lead was calculated from the slopes of the measured curves. The slope was read from the measured data for the last $72 \mathrm{~h}$ of exposure. Figure 2 gives an example of evaluation of the lead corrosion rate on the basis of changes in the metal trace in dependence on time.

\section{Analysis of the corrosion products and documentation of the surface of lead samples after exposure}

Lead samples with a size of $3 \times 3 \mathrm{~cm}$ were also exposed parallel with the resistometric probes in the manner 


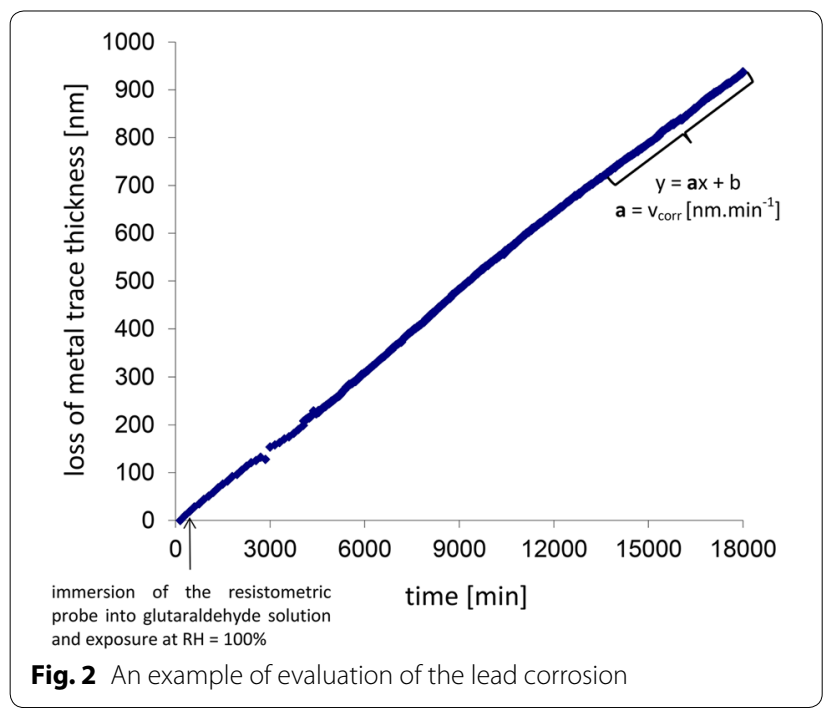

described in "Determination of the lead corrosion rate $\left(\mathrm{v}_{\text {corr }}\right)$ using resistometric probes". After completion of the exposure, the surface of the lead samples was analysed using the PANanalytical X'pert PRO XRD spectrometer and Nicolet iN 10 infrared spectrometer. The corrosion products on the surface of the lead samples following exposure were documented using a TESCAN VEGA 3 scanning electron microscope both in the secondary electrons (SE) regime and in the back-scattered electrons (BSE) regime.

\section{Results and discussion}

The value of the polarisation resistance describes the corrosion rate of the lead sample after sanding and $30 \mathrm{~min}$ exposure in a solution. It follows from the results of measurements of the polarisation resistance that lead has the highest corrosion rates in solutions of $2.5 \%$ glutaraldehyde $\left(\mathrm{Rp}=0.7 \Omega \mathrm{m}^{2}\right)$ and $2 \%$ carbethopendecinium bromide $\left(\mathrm{Rp}=0.4 \Omega \mathrm{m}^{2}\right)$. In comparison, the corrosion rate of lead is lowest in a $96 \%$ butanol solution $(\mathrm{Rp}=78.5$ $\Omega \mathrm{m}^{2}$ ) see Table 1 . The corrosion rate in the comparison solution of artificial rain water after $30 \mathrm{~min}$ of exposure is comparable with the corrosion rates in solutions of $2.5 \%$ glutaraldehyde and $2 \%$ carbethopendecinium bromide. This is because passive oxide layers were not formed on the lead surface during $30 \mathrm{~min}$ exposure in an artificial rain water solution.

The corrosion resistance was also evaluated by resistometric probe measurement. (The measuring part of the resistometric probes was exposed by immersion and followed by drying. Measurements were performed over vapours only when using butanol-see "Determination of the lead corrosion rate $\left(\mathrm{v}_{\text {corr }}\right)$ using resistometric
Table 2 Comparison of the $R p$ values of lead in the solutions and resistometric $v_{\text {corr }}\left(\mathrm{mm} \mathrm{a}^{-1}\right)$ values of lead after contaminated by the solutions and exposed in a humid atmosphere

\begin{tabular}{|c|c|c|}
\hline Disinfectants & $\operatorname{Rp}\left(\Omega \mathrm{m}^{2}\right)$ & $\begin{array}{l}\mathrm{v}_{\text {corr }}\left(\mathrm{mm} \mathrm{a}^{-1}\right) \\
\text { Resistometric probe }\end{array}$ \\
\hline Artificial rain water & 0.2 & $7 \times 10^{-3}$ \\
\hline $\begin{array}{l}\text { Carbethopendecinium } \\
\text { bromide }\end{array}$ & 0.4 & 0.21 \\
\hline Glutaraldehyde & 0.7 & 0.23 \\
\hline Bacillol AF & 1.3 & $1 \times 10^{-3}$ \\
\hline Butanol & 78.5 & $1 \times 10^{-3}$ \\
\hline
\end{tabular}

probes"). High corrosion rates of lead were recorded in a $2 \%$ carbethopendecinium bromide $\left(0.21 \mathrm{~mm} \mathrm{a}^{-1}\right)$ solution and in a $2.5 \%$ glutaraldehyde solution $\left(0.23 \mathrm{~mm} \mathrm{a}^{-1}\right)$. In comparison, the corrosion rate in an alcohol-based disinfectant media was very low (Table 2). In a solution of 1-propanol, 2-propanol and ethanol in an approximate ratio of 10:6:1 (Bacillol AF) and 96\% butanol, the lead corrosion rate attained a value of $1 \times 10^{-3} \mathrm{~mm} \mathrm{a}^{-1}$, which was comparable with the lead corrosion rate in artificial rain water, $7 \times 10^{-3} \mathrm{~mm} \mathrm{a}^{-1}$ (Table 2). The low lead corrosion rate in a Bacillol AF, $96 \%$ butanol and a solution of artificial rain water after $300 \mathrm{~h}$ of exposure is caused by the passive oxidation layer on its surface.

It follows from the results of XRD analysis that the corrosion products of lead samples that were exposed to alcohol-based disinfectant solutions had approximately the same composition. They formed a mixture of $\mathrm{PbO}$ and $\mathrm{Pb}_{3}\left(\mathrm{CO}_{3}\right)_{2}(\mathrm{OH})_{2}$. A lead sample that was exposed in an artificial rain water solution yielded the same corrosion products. The corrosion products on the surface are not visible to the naked eye (Figs. 3, 4, 5).

A lead sample that was exposed in a solution of $2 \%$ carbethopendecinium bromide contained, in a mixture of $\mathrm{PbO}$ and $\mathrm{Pb}_{3}\left(\mathrm{CO}_{3}\right)_{2}(\mathrm{OH})_{2}$, also $\mathrm{Pb}\left(\mathrm{NO}_{3}\right)_{2}$, which was formed by the reaction of lead with QAS. The surface of the lead sample was covered with a clearly visible layer of corrosion products (Fig. 6).

A crystalline phase with a large organic component was also identified using XRD analysis in a mixture of $\mathrm{PbO}$ and $\mathrm{Pb}_{3}\left(\mathrm{CO}_{3}\right)_{2}(\mathrm{OH})_{2}$ in the corrosion products of a lead sample that was exposed in a solution of $2.5 \%$ glutaraldehyde. The corrosion products were also analysed by the infrared spectroscopic method. The crystalline phase containing a larger organic component was identified as the lead salt of glutaric acid. Glutaraldehyde reacts very readily with lead II ions in a damp medium to form glutaric acid according to the equation [24]: 


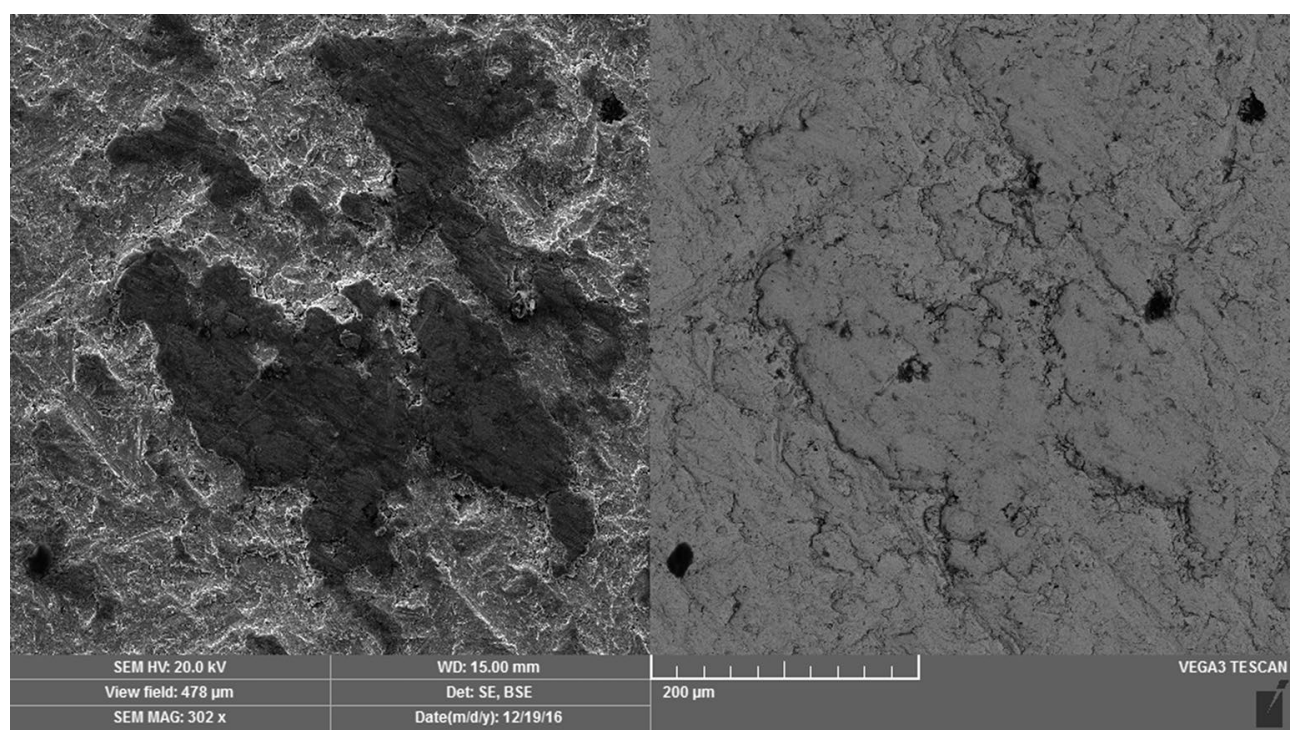

Fig. 3 A lead sample after exposition in an artificial rain water

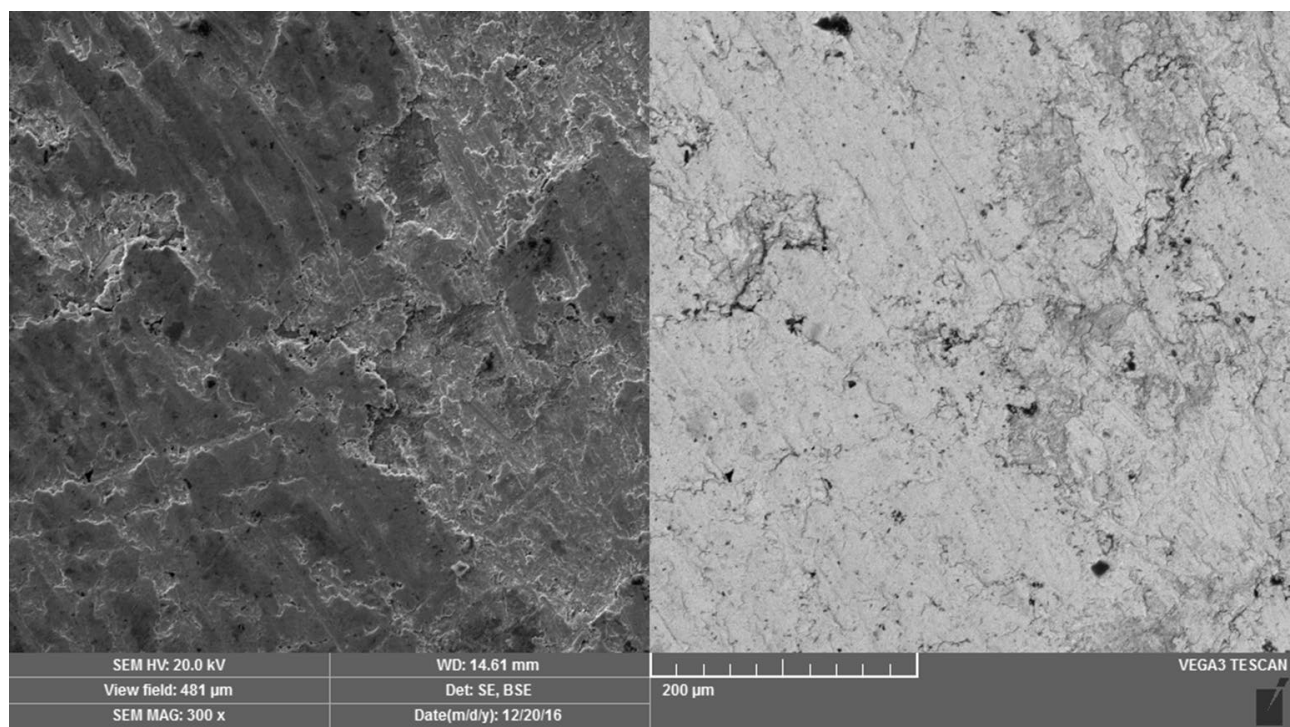

Fig. 4 A lead sample after exposition in 96\% butanol vapours

$$
\begin{aligned}
\mathrm{O}= & \mathrm{CH}-\mathrm{CH}_{2}-\mathrm{CH}_{2}-\mathrm{CH}_{2}-\mathrm{CH}=\mathrm{O}+\mathrm{Pb}^{2+}+2 \mathrm{H}_{2} \mathrm{O} \\
& \rightarrow \mathrm{Pb}+\mathrm{HOOC}-\mathrm{CH}_{2}-\mathrm{CH}_{2} \\
& -\mathrm{CH}_{2}-\mathrm{COOH}+2 \mathrm{H}^{+}
\end{aligned}
$$

Glutaric acid is readily soluble in water. It reacts further with lead to form lead II glutarate:

$$
\begin{gathered}
2 \mathrm{HOOC}-\mathrm{CH}_{2}-\mathrm{CH}_{2}-\mathrm{CH}_{2}-\mathrm{COOH}+\mathrm{Pb}+1 / 2 \mathrm{O}_{2} \\
\quad \rightarrow \mathrm{HOOC}-\mathrm{CH}_{2}-\mathrm{CH}_{2}-\mathrm{CH}_{2}-\mathrm{COO}-\mathrm{Pb} \\
-\mathrm{OOC}-\mathrm{CH}_{2}-\mathrm{CH}_{2}-\mathrm{CH}_{2}-\mathrm{COOH}+\mathrm{H}_{2} \mathrm{O}
\end{gathered}
$$

The value of $\mathrm{E}_{\mathrm{RED} / \mathrm{Ox}}$ potential is - $240 \mathrm{mV} / \mathrm{SHE}$ does not exlude the possibility of oxidation of lead in the glutaric acid (measured on the inert electrode by potentiostat Gamry PC 3). Glutaric acid very probably acts as a catalyst in this process. The surface of the lead sample was covered with a clearly visible layer of corrosion products (Fig. 7).

After application of a disinfectant reagent consisting of a $2 \%$ carbethopendecinium bromide solution and a $2.5 \%$ glutaraldehyde solution, the corrosion rate of lead is substantially higher compared with alcohol-based 


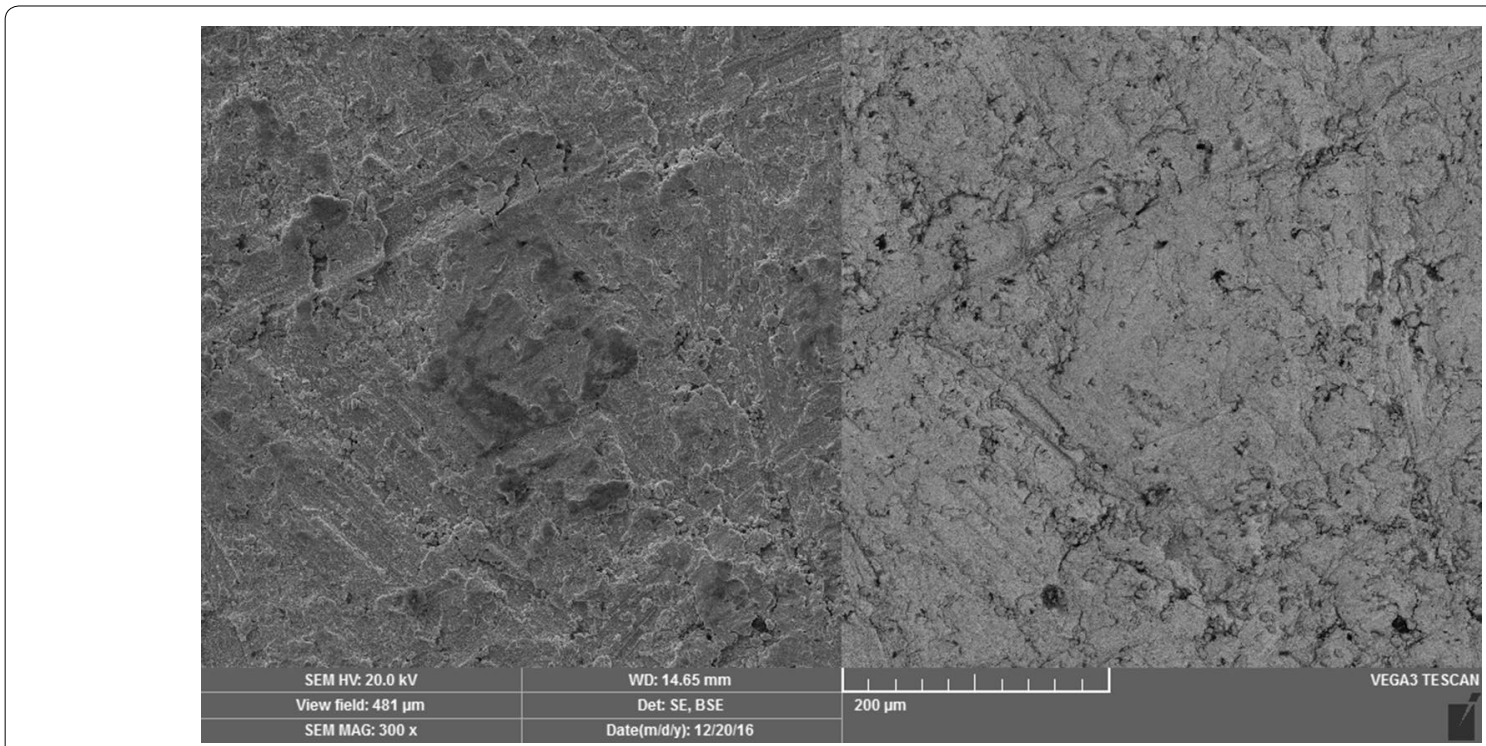

Fig. 5 A lead sample after exposition in a Bacillol AF

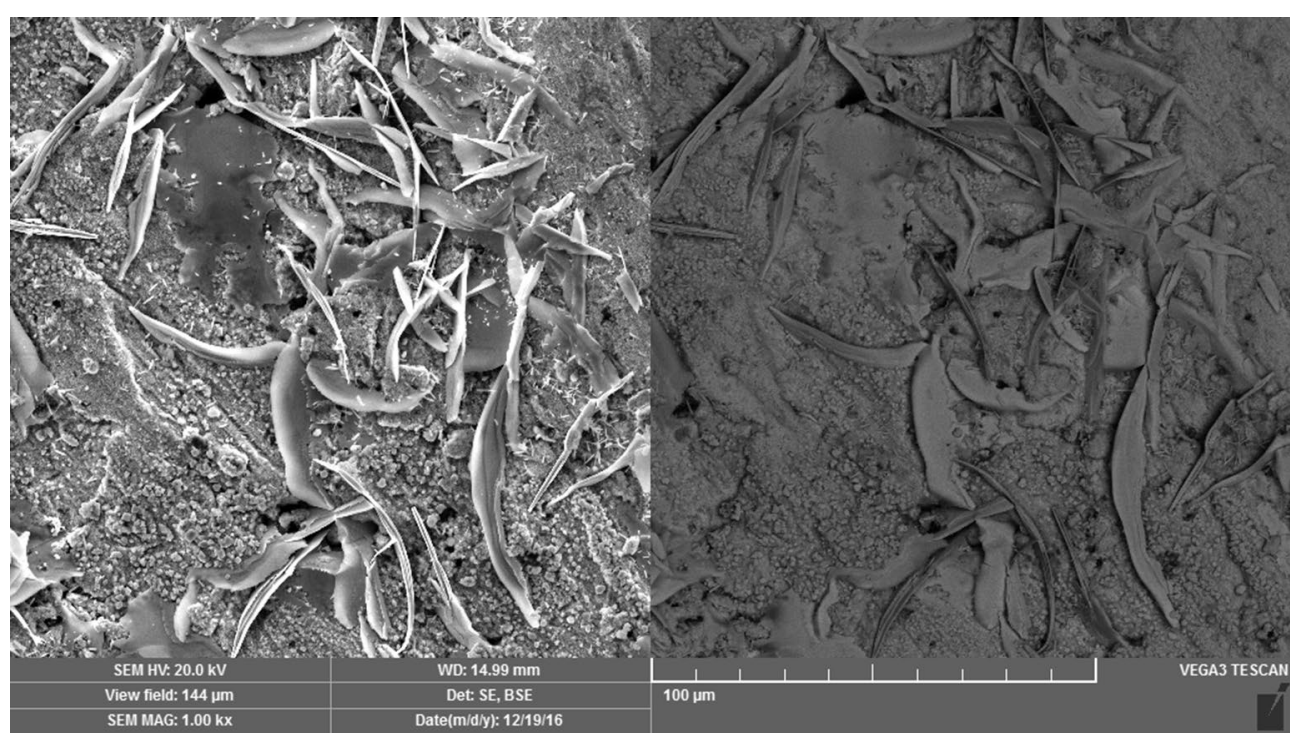

Fig. 6 A lead sample after exposition in a carbethopendecinium bromide solution

disinfectant agents. This is because of their reactivity with the lead surface, leading to active lead corrosion.

\section{Conclusion}

Alcohol-based disinfectant reagents cause the least damage to a lead surface and, when they are used, the corrosion rate of lead is the lowest compared with the other tested disinfectant agents. A 96\% butanol solution is most suitable for vapour applications. A solution of 1-propanol, 2-propanol and ethanol in an approximate ratio of 10:6:1 (Bacillol AF, alcohol) is more suitable for immersion applications. The corrosion rate of lead disinfectant solutions of a carbethopendecinium bromide and glutaraldehyde was substantially higher compared with alcohol-based disinfectant agents. This is because of their reactivity with lead, leading to the formation 


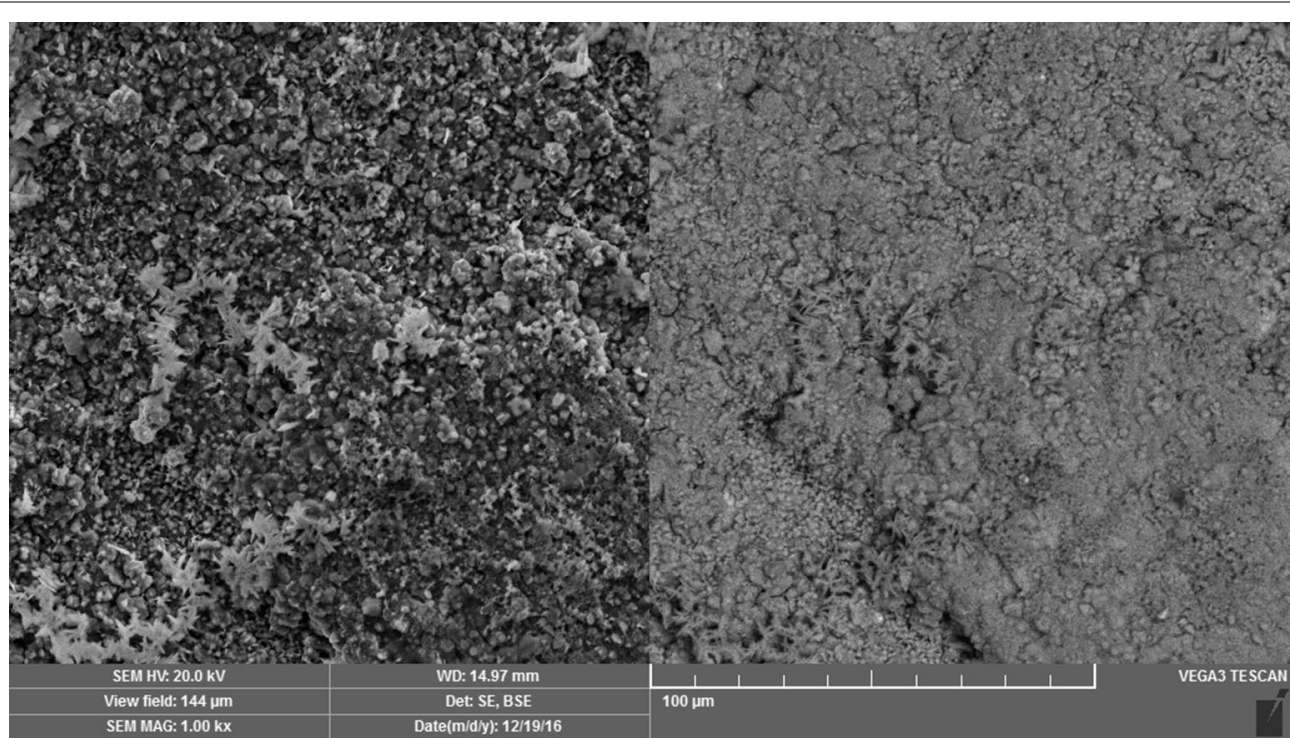

Fig. 7 A lead sample after exposition in a glutaraldehyde solution

of soluble corrosion products and damage to the lead surface. Thus their use for the disinfection of historical documents with lead seals cannot be recommended.

\section{Abbreviations}

QAS: quaternary ammonium salts; Rp: polarization resistance; SCE: saturated calomel electrode; EOC: open circuit potential; $v_{\text {corr }}$ corrosion rate; Bacillol AF: solution of 1-propanol, 2-propanol and ethanol.

\section{Authors' contributions}

MS (main author) analysed lead surfaces and made photos using SEM and interpreted the Rp data and the resistometric probes data. KM managed the resistometric test. SCHK contributed in writing of the manuscript introduction. SJ managed the electrochemical test. PK and DP prepared the lead samples and probes for electrochemical and resistometric test. All authors read and approved the final manuscript.

\section{Competing interests}

The authors declare that they have no competing interests.

\section{Availability of data and materials}

The dataset analysed during the current study are available from the corresponding author on request.

\section{Funding}

The financial support of NAKI II (Project DG16P02R040) is gratefully acknowledged.

\section{Publisher's Note}

Springer Nature remains neutral with regard to jurisdictional claims in published maps and institutional affiliations.

Received: 12 November 2018 Accepted: 12 March 2019 Published online: 21 March 2019

\section{References}

1. Bell HI. A list of original papal bulls and briefs in the Department of Manuscripts, British Museum. Engl Hist Rev. 1921;36:393-419.

2. Eitel A. Über Blei-und Goldbullen im Mittelalter. Ihre Herleilung und ihre erste Verbreitung. 1st ed. Freiburg im Breisigau; 1912.

3. Jurek T. Funkcje i symbolika polskich bulli książęcych. In: Moc a její symbolika ve středověku. Praha: Filosofia; 2011. p. 11-31.

4. Cotsonis J. The contribution of Byzantine Lead seals to the study of the cult of the saints (sixth-twelfth century). Byzantion. 2005:75:383-497.

5. Whatley L. A companion to seals in the middle ages. Boston: Brill; 2019.

6. Kukánková Z. Složení olověných bul ve Státním ústředním archivu. In: IX.seminár konzervátorů a historiků. Praha : Státní ústřední archiv v Praze; 1994. p. 142-4.

7. Hlaváček I, Kašpar J, Nový R. Vademecum pomocných věd historických. 4th ed. Jinočany: H\&H; 1997.

8. Leygraf Ch, Wallinder IO, Tidblad J, Graedel T. Atmospheric corrosion. 2nd ed. New Jersey: Wiley; 2016.

9. Selwyn L. Metals and corrosion: handbook of conservation professional. 1st ed. Ottawa: Canadian Conservation Institute; 2004.

10. Pecenová Z, Kouriil M. Protection of Historical Lead against Acetic Acid Vapour. Koroze a ochrana materiálu. 2016;60(1):28-34.

11. Ryhl-Svendsen M. Corrosivity measurements of indoor museum environments using lead coupons as dosimeters. J Cult Heritage. 2008;9:285-93.

12. Edwards R, Bordass W, Farrell D. Determination of acetic acid and formic acid in lead corrosion products by ion-exchange chromatography. Analyst. 1997;12:1517-20.

13. Raychaudhuri MR, Brimblecombe P. Formaldehyde oxidation and lead corrosion. Stud Conserv. 2000;45:226-32.

14. Kowalik R. Microbial deterioration of library materials. Restaurator. 1980;4:135-219.

15. Dernovšková J, Zelinger J. An investigation of the hygroscopicity of parchment subjected to different treatments. Restaurator. 1995;16:31-44.

16. Bacilková B. Study on the effect of butanol vapours and other alcohols on fungi. Restaurator. 2006;27(3):186-99.

17. Karbowska-Berent J, Kozielec T, Jarmiłko J, Brycki B. Possible application of quaternary ammonium salts for disinfection of paper based objects. Restaurator. 2011;32:223-46.

18. Kennedy CJ, Vest M, Cooper M, Wess TJ. Laser cleaning of parchment: structural, thermal and biochemical studies into the effect of wavelength and fluence. Appl Surf Sci. 2004;227:151-63. 
19. Shirakawa MA, Gaylarde CC, Sahao HD, Lima JRB. Inhibition of cladosporium growth on gypsum panels treated with nanosilver particles. Int Biodeterior. Biodegrad. 2013;85:57-61.

20. lannuccelli S, Sotgiu S. Wet treatments of works of art on paper with rigid gellan gels. In: The book and paper group annual, AIC's 38th annual meeting. 2010.

21. De Filpo G, Palermo AM, Munno R, Molinaro L, Formoso P, Nicolleta FP. Gellan gum/titanium dioxide nanoparticle hybrid hydrogels for the cleaning and disinfection of parchment. Int Biodeterior Biodegrad. 2015;103:51-8.
22. Jones DA. Principles and prevention of corrosion. 2nd ed. New Jersey: Prentice Hall; 1996.

23. Kouřil M, Prošek T, Dubus $M$, Taube M, Hubert $V$, Scheffel B, Degres $Y$, Jouannic M, Thierry D. Corrosion monitoring in the hands of restorers and conservators. Koroze a ochrana materiálů. 2013;56(3):67-75.

24. Červinka O, Dědek V, Ferles M. Organická chemie. 2nd ed. Prague: SNTL; 1982.

\section{Submit your manuscript to a SpringerOpen ${ }^{\odot}$} journal and benefit from:

- Convenient online submission

- Rigorous peer review

- Open access: articles freely available online

- High visibility within the field

- Retaining the copyright to your article

Submit your next manuscript at $\boldsymbol{\nabla}$ springeropen.com 